\title{
The importance of storytelling in chemical education
}

\author{
Storytelling can be a powerful educational tool to help address equity in the chemical sciences.
}

\author{
Sibrina N. Collins
}

m magine a chemistry professor leading a laboratory discussion with a group of students about organic esters, those carboxylic acid derivatives that are so important for many societal needs. While talking through their practical applications, the professor shares an image of a young African American chemist named Alice Augusta Ball and tells the students about her contributions to chemistry, medicine and society. In the early twentieth century, Ball developed the first viable treatment for leprosy (also known as Hansen's disease) by successfully synthesizing ethyl esters from extracts of chaulmoogra tree seed oil. Chaulmoogra seed oil had been used as a remedy against this terrible disease with mixed results - the oil was thick and not particularly soluble in water, which meant that injections of it were painful (causing blisters and abscesses) and rather inefficient. Ball's breakthrough was to convert the active ingredients, long-chain carboxylic acids, into esters that could be injected in patients much more easily, resulting in much higher therapeutic success rates ${ }^{1}$.

To further emphasize Ball's scientific contributions, in addition to mentioning her highly unusual position - she was both the first African American and the first woman to become a chemistry instructor at the College of Hawaii (now the University of Hawaii) - the professor highlights that leprosy was, at the time, a serious public health crisis. The challenges in developing therapeutics to treat it were perhaps not too dissimilar to the current issues we face with COVID-19. Unfortunately, Ball died at the young age of 24. She didn't see the full impact of her scientific contributions and society also missed out on any advances that would have come from her further work. Yet, beyond Ball's chemical and medical legacy, one way her story can continue to be impactful is simply by being shared widely - this shouldn't be overlooked. Imagine the effect of sharing Ball's story with chemistry students, particularly women and students of colour.

I was fascinated by Ball's scientific accomplishments, and because I adore

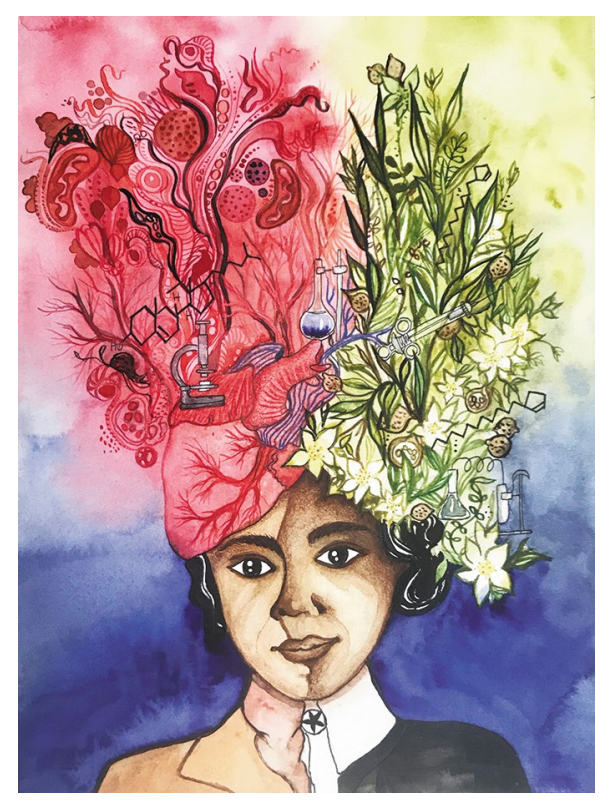

Credit: Giulia Lampis

the fields of history and history of science, I wrote about her story ${ }^{2}$. This led to a collaboration with Marie Anne Torres-Lopez in 2019. While studying media communications at Lawrence Technological University, leading a team of students, Torres-Lopez wrote, directed and produced a powerful 30-minute documentary entitled Women Untold, which includes Ball's story ${ }^{3}$. Prior to a laboratory exercise focused on organic esters, I would suggest that chemistry professors encourage their students to watch the film, not only to grasp the importance of esters, but also to inspire students to share their own experiences about overcoming barriers in life. In this manner, chemistry students would be given the opportunity to incorporate their own stories in chemical education.

The problem is that few chemistry faculty teach in this way and they often miss the opportunity to intertwine classroom content with the stories and intellectual achievements of women and chemists of colour. Chemists can tell very compelling stories using the molecules or systems that we choose to investigate; why not tell the stories of the chemists behind the compounds too - such as that of Ball while discussing organic esters - ensuring that everyone's contributions are captured?

A few years ago, in American Scientist, Nobel Laureate Roald Hoffmann pondered on the importance of scientific storytelling in research articles ${ }^{4}$. Conducting a literary analysis of, as an example, the first report of Taxol synthesis in 1994, Hoffman writes, "Note the dual protagonist of this tale: the molecule to be sure, and the chemists who made it." He also emphasizes "Science has stories to it. Scientists shape these stories, and the protagonists of these stories need not be human. These narrative qualities are not only important to composing research papers, but also to effective teaching." Indeed, both Ball and the organic esters are protagonists in the tale that led to a treatment for leprosy.

As much as I love being an inorganic chemist and enjoyed my studies in this field, I never saw myself reflected in the chemical sciences while pursuing my education - I rarely saw images of Black chemists in textbooks or anywhere else throughout the chemistry curriculum. An important goal of my teaching philosophy as a chemistry professor was to change that in my classroom. I wanted to incorporate storytelling in the curriculum to broaden the image of a chemist for all the students enrolled on my courses.

Although a wide variety of anecdotes can be associated with class content, my approach to storytelling in chemical education really focuses on addressing equity in the field. Ball's story is just one example; that of Marie Maynard Daly is equally fascinating. Daly is the first African American woman to have earned a PhD in chemistry in the United States (Columbia University, 1947) - and yes, that historical 'first' is compelling in itself. She investigated the critical relationship between cholesterol and heart attacks in the 1950s, which is still very relevant in today's society. Daly's story could certainly be incorporated in the 
chemistry curriculum with content focused on steroid chemistry, along with that of organic chemist Percy Lavon Julian, whose brilliant contributions to birth control and treatments for arthritis and glaucoma have had lasting impacts. Imagine an organic chemistry curriculum that features the stories of Ball, Daly and Julian! That's powerful storytelling, poised to not only draw the attention of chemistry students to the scientific importance of the compounds discussed, but also to address equity in chemical education ${ }^{6}$.

As an inorganic chemistry professor teaching at a predominately undergraduate institution (PUI) in the Midwestern region of the USA, I shared the story of Gregory $\mathrm{H}$. Robinson in the classroom with third-year chemistry majors. Robinson is an inorganic chemistry professor who, in 1997, published a ground-breaking paper on the first ferrogallyne - a compound containing an iron-gallium triple bond - while I was a graduate student in the Department of Chemistry at The Ohio State University ${ }^{7}$. That same year, the group led by Robinson also reported a compound that contained a gallium-gallium triple bond ${ }^{8}$. This discovery was widely challenged in the inorganic chemistry community ${ }^{9}$, focusing on the fact that no triple bonds between these elements had previously been reported. No formal consensus was reached at the time; in 1999, Robinson specifically described the Ga-Ga interaction as "two weak donor-acceptor bonds and one $\pi$-bond" 10 . This episode had a profound impact on me - an inorganic chemist that actually looks like me, conducting ground-breaking research and challenging our thinking about metal-metal bonding?! Wow!

As a professor in 2012, recalling the impact that these developments had on me and my own education, I used them to develop a case study to engage the next generation of chemists while letting them learn about Robinson's story ${ }^{11}$. Through this session, the students worked on the concepts of bond order and how it relates to bond length and molecular orbital theory. They were placed in three teams, defending either a single, double or triple bond argument in class. They were encouraged to think about the new insights into the bonding of main-group compounds, but also about the perspective of the people behind the scientific arguments. All of the students took part in a role-playing exercise, acting as the researchers involved in the story, proposing points and counter-points. Compared to what is illustrated in most textbooks, the exercise conveyed a more diverse image of who can be a chemist. I was tremendously proud of these young chemistry majors for their level of engagement and effort.

At other times, it is a molecule that takes centre stage and grabs the attention of a chemist. The motivation for my own research was cisplatin, an anticancer drug widely used against various types of tumours ${ }^{12,13}$. Together with my students and research collaborators, I focused on developing metal-based therapeutics for treating lung cancer. What I found fascinating about the story of cisplatin (or cis-diamminedichloroplatinum(II)) is that it was first reported ${ }^{14}$ in literature in 1844 , by the Italian chemist Michele Peyrone, yet it would be over a century before its anticancer behaviour was discovered and subsequently described ${ }^{15}$ in 1965 . Its antitumour activity was discovered accidentally by US-based researchers Rosenberg, Van Camp and Krigas while they were investigating the role of electric currents on cell division using Escherichia coli cells in ammonium chloride buffer with platinum electrodes ${ }^{16}$. This truly fascinating development makes cisplatin an interesting protagonist in drug discovery stories to be shared with chemistry students.

Storytelling does not have to be limited to compounds and people, we can also use fiction to engage the next generation of chemists. The fictional element vibranium was one of the protagonists in Marvel Studios' Black Panther, starring the late Chadwick Boseman in the lead role. As a chemist, I was absolutely fascinated by its role as the primary source for science and technology advances in the fictional country of Wakanda. In 2018, together with my colleague LaVetta Appleby, I described a fun strategy to engage students in learning and understanding the organization of the periodic table of elements: asking them where they would place vibranium on the table and why ${ }^{17}$. Additionally, Black Panther is a very compelling story about women and scientists of colour developing creative and innovative solutions to solve societal challenges - an important narrative to include within chemistry education. The popular movie is an excellent resource for student engagement and teaching, from trends of the periodic table, to the behaviour of transition metals, to relativistic effects ${ }^{18}$.

How can chemistry professors engage their students more effectively in the classroom and beyond? Simply by telling compelling stories about compounds, chemists and even fictional science. Effective storytelling in chemical education is important and matters. Imagine a chemistry curriculum that was truly inclusive and celebrated the intellectual achievements of everyone. Now, that would be a compelling story. The chemistry community can do so much better.

\section{Sibrina N. Collins}

The Marburger STEM Center, Lawrence

Technological University, Southfield, MI, USA.

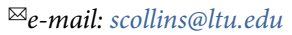

Published online: 22 December 2020

https://doi.org/10.1038/s41557-020-00617-7

References

1. Wermager, P. \& Heltzl, C. Chem. Matters 25, 16-19 (2007).

2. Collins, S. N. Alice Augusta Ball: chemical drug pioneer. Undark Magazine https://go.nature.com/AliceAugustaBall (2016).

3. Torres-Lopez, M. A. et al. Women Untold. Youtube https:// go.nature.com/YoutubeWomenUntold (2019).

4. Hoffmann, R. The tensions of scientific storytelling. Am. Sci. https://doi.org/10.1511/2014.109.250 (2014).

5. Collins, S. N. Unsung: Marie Maynard Daly. Undark Magazine https://go.nature.com/MarieMaynardDaly (2017).

6. O'Brien, A. T. Percy L. Julian: 'forever fight to keep hope alive!' Chem. Eng. News https://go.nature.com/PercyLJulian (2007).

7. Su, J., Li, X.-W., Crittendon, R. C., Campana, C. F. \& Robinson, G. H. Organometallics 16, 4511-4513 (1997).

8. Su, J., Li, X.-W., Crittendon, R. C. \& Robinson, G. H. J. Am. Chem. Soc. 119, 5471-5472 (1997).

9. Dagani, R. Gallium 'triple bonds' under fire. Chem. Eng. News. http://pubsapp.acs.org/cen/hotarticles/cenear/980316/ gal.html (1998)

10. Robinson, G. H. Acc. Chem. Res. 32, 773-782 (1999).

11. Collins, S. N. Gallium chemistry: to be or not to be a triple bond! IONiC VIPEr (2012); https://www.ionicviper.org/classactivity/ gallium-chemistry-be-or-not-be-triple-bond

12. Dasari, S. \& Tchounwou, P. B. Eur J. Pharmacol. 740, 364-378 (2014).

13. Date, T. Cisplatin: a journey to a solution for triple-negative breast cancer. OncoBites https://go.nature.com/OncoBitesCisplatin (2020).

14. Kauffman, G. B., Pentimalli, R., Doldi, S. \& Hall, M. D. Platinum Metals Rev. 54, 250-256 (2010).

15. Rosenberg, B., Van Camp, L. \& Krigas, T. Nature 205, 698-699 (1965)

16. Alderden, R. A., Hall, M. D. \& Hambley, T. W. J. Chem. Educ. 83, 728-734 (2006)

17. Collins, S. N. \& Appleby, L. J. Chem. Educ. 95, 1243-1244 (2018)

18. Collins, S. N. Advances in Teaching Inorganic Chemistry Volume 1: Classroom Innovations and Faculty Development Ch. 8, 87-95 (American Chemical Society, 2020).

Competing interests

The author declares no competing interests. 